ISSN 1693-3079

\title{
PENGARUH ORAL HYGIENE TERHADAP MALNUTRISI PADA LANSIA (Kajian Pustaka)
}

\author{
Pindobilowo \\ Staf Laboratorium Ilmu Kesehatan Gigi Masyarakat FKG UPDM (B) Jakarta
}

\begin{abstract}
ABSTRAK
Lansia merupakan suatu proses alami dimana terjadi perubahan fungsi jaringan tubuh dan organ yang sangat kompleks. Pada Lansia terjadi penurunan kemampuan berbagai jaringan tubuh secara perlahan-lahan. Penurunan kondisi ini terjadi pada berbagai organ tubuh, antara lain melemahnya daya ingat, perubahan sensorik, dan perubahan pada kondisi oral hygiene. Oral hygiene dapat mempengaruhi status gizi dan kesehatan umum lansia. Pada tahun 2000 jumlah penduduk lansia di dunia mencapai 426 juta jiwa atau sekitar 6,8\% dari total populasi dan perkiraan akan mengalami peningkatan dua kali lipat pada tahun 2025. Di kawasan Asia Tenggara jumlah populasi lansia sekitar 142 juta jiwa atau sekitar $8 \%$, sedangkan di Indonesia data terakhir tahun 2014 menunjukkan jumlah penduduk lansia mencapai 20,24 juta jiwa atau sekitar 8\% dan Indonesia diperkirakan terjadi peningkatan jumlah populasi lansia di wilayah Asia pada tahun 2050. Jumlah kasus lansia yang malnutrisi di Indonesia adalah sebesar 3,4\%. Melihat fenomena ini, maka kesehatan lansia perlu ditingkatkan khususnya oral hygiene sehingga terjadi keseimbangan nutrisi dan mempengaruhi kondisi umum lansia. Tujuan penelitian ini adalah untuk mengetahui pengaruh oral hygine terhadap malnutrisi pada lansia.
\end{abstract}

Kata kunci : Lansia, Malnutrisi, Oral hygiene

\section{ABSTRACT}

Elderly is a very complex natural process that changes in function of body tissues and organs. In the elderly there is a slowly decrease in the ability of various tissues of the body. The decline in this condition occur in various organs of the body, including memory retardation, sensory changes, and changes in oral hygiene conditions. Oral hygiene may affect nutritional status and general health of the elderly. In 2000, number of elderly people in the world reached 426 million people or about $6.8 \%$ of the total population and the 142 million people or about $8 \%$. Indonesia the last data of 2014 shows the number of elderly population reached 20.24 million people or about $8 \%$ and Indonesia is estimated to increase the number of elderly population in the Asian region in the year 2050. The number of malnutrition elderly cases in Indonesia is $3.4 \%$. Seeing this phenomenon, the elderly health needs especially oral hygiene to be increased, so there are the balance of nutrients and the effect of general condition of elderly. The purpose of this study was to determine the effect of oral hygiene on malnutrition in the elderly

Key words: Elderly, Malnutrition, Oral hygiene

\section{PENDAHULUAN}

$\mathrm{L}$ ansia merupakan kelompok umur pada manusia yang telah memasuki tahapan akhir dari fase kehidupan. Menurut WHO lansia dikelompokkan menjadi 4 kelompok, yaitu usia pertengahan (middle age) antara usia 45-59 tahun, lansia (elderly) antara usia 60-74 tahun, lansia tua (old) antara usia 75-90 tahun, dan lansia sangat tua (very old) diatas 90 tahun. Menurut Hadywinoto dan Setiabudi (1999). lansia adalah manusia yang berusia 60 tahun keatas. Pada lansia akan terjadi suatu proses yang disebut aging process. Proses penuaan adalah siklus kehidupan yang ditandai dengan tahapan-tahapan menurunnya berbagai jaringan tubuh secara perlahan-lahan, meliputi kondisi fisik dan psikis. ${ }^{1,2,3}$

Salah satu ciri kependudukan abad 21 adalah meningkatnya pertumbuhan penduduk lansia yang sangat cepat. Pada tahun 2000 jumlah penduduk lansia di seluruh dunia mencapai 426 juta atau sekitar 6,8\% dari total populasi dan diperkirakan akan mengalami peningkatan dua kali lipat pada tahun 2025. Di India jumlah lansia di atas 60 tahun yaitu mencapai 76 juta atau sekitar 7,6\% dari jumlah populasi. Di kawasan Asia Tenggara jumlah populasi lansia adalah 142 juta atau sekitar $8 \%$ dari populasi, sedangkan di Indonesia data terakhir jumlah lansia tahun 2014 sebesar 20,24 juta atau sekitar 8\% dari populasi. Jika dilihat dari sebaran penduduk lansia berdasarkan propinsi di Indonesia, 
presentase penduduk lansia yang paling tinggi ada di propinsi DI Yogyakarta (13,04\%), Jawa Timur (10,40\%), dan Jawa Tengah (10,34\%), sedangkan jumlah lansia di propinsi DKI Jakarta sebesar 5,24\%, dengan jumlah lansia wanita lebih besar daripada laki-laki.,3,4

Malnutrisi sering dialami oleh lansia, salah satu penyebabnya adalah kehilangan gigi. Jumlah kasus lansia yang malnutrisi di Indonesia adalah sebesar 3,4\% dan prevalensi kehilangan gigi pada lansia usia 64-70 tahun di Indonesia adalah sebesar 23,5\%. Data yang di dapat dari $W H O$, prevalensi kehilangan gigi pada populasi usia $65-75$ tahun di negara Perancis $16,9 \%$, Jerman $24,8 \%$, dan di USA $31 \%$. Indonesia memiliki angka kehilangan gigi yang tergolong tinggi yaitu sebesar $24 \%$ penduduk dengan kondisi tidak bergigi pada masyarakat yang berumur diatas 65 tahun. ${ }^{5}$

Kebersihan mulut atau oral hygiene masih menjadi masalah utama lansia. Secara umum problem kesehatan gigi dan mulut yang paling sering dialami oleh lansia adalah kehilangan gigi oleh karena karies dan penyakit jaringan periodontal. Buruknya oral hygiene pada lansia bisa mempengaruhi kesehatan umum dan status gizi karena fungsi pengunyahan berkurang secara bertahap, Hal ini akan menyebabkan perubahan diet yang disebabkan karena lansia menghindari beberapa makanan tertentu, khususnya makanan yang sulit untuk di kunyah. $., 6,7,8$

\section{TINJAUAN PUSTAKA}

\section{Pengaertian lansia}

Menurut Departemen Kesehatan Republik Indonesia dalam Undang-Undang Kesehatan No.13 Tahun 1998 Pasal 1 Ayat 2, 3, dan 4 mangatakan bahwa lansia adalah seseorang yang telah mencapai usia 60 tahun keatas, dan dikelompokkan menjadi :5

a. Pra lanjut usia yaitu usia 45-59 tahun

b. Lanjut usia yaitu usia 60-69 tahun

c. Lanjut usia dengan risiko tinggi yaitu usia 70 tahun atau lebih dengan masalah kesehatan

Menurut Papalia (2001) usia tua sering disebut senescence merupakan periode dari rentang kehidupan yang ditandai dengan perubahan dan penurunan fungsi tubuh. Ada beberapa hal yang dapat digunakan untuk memahami usia tua, antara lain : ${ }^{5}$

\section{a. Primary aging}

Proses primary aging merupakan suatu proses penurunan atau kerusakan fisik yang terjadi secara bertahap dan bersifat inevitable (tidak dapat dihindarkan).

\section{b. Secondary aging}

Proses secondary aging merupakan hasil dari penyakit, abuse, dan disuse pada tubuh yang seringkali lebih dapat dihindari dan dikontrol oleh individu dibandingkan dengan primary aging, misalnya dengan pola makan yang baik, menjaga kebugaran fisik dll

Usia tua sangat rentan terhadap penyakit ini disebabkan karena terjadi penurunan organ dan daya tahan tubuhnya. Menurut Guntur (2006) proses menua merupakan menghilangnya secara perlahan-lahan kemampuan jaringan untuk memperbaiki diri sehingga organ tubuh sulit untuk mempertahankan fungsi normalnya sehingga tubuh tidak dapat bertahan terhadap infeksi. Oleh karena itu pada lansia banyak sekali timbul penyakit degeneratif. Penyakit-penyakit degeneratif yang sering di alami oleh lansia, diantaranya: penyakit jantung koroner, hipertensi, diabetes mellitus, osteoarthritis, dan osteoporosis. ${ }^{6}$

2. Kebutuhan nutrisi pada lansia

Lansia merupakan salah satu kelompok yang rawan menderita kekurangan gizi, ini disebabkan karena penurunan sensori indra perasa dan penciuman, yang disebabkan atropi indra pengecap sehingga terjadi penurunan sensitivitas karena adanya iritasi kronis, gangguan fungsi pengunyahana akibat hilangnya banyak gigi oleh karena penyakit periodontal, gangguan saluran pencernaan, gangguan neurologi, cacat fisik dan penyakit lain seperti kanker. Nutrisi merupakan suatu asupan yang mengandung gizi yang dibutuhkan tubuh untuk proses metabolisme. Secara umum kebutuhan nutrisi pada lansia sedikit lebih rendah dibandingkan pada usia dewasa, oleh karena itu pemenuhan gizi pada lansia dengan baik dapat membantu dalam proses pergantian sel-sel tubuh sehingga dapat meningkatkan kualitas hidup dan memperpanjang usia lansia. Apabila asupan nutrisi pada lansia berkurang maka dapat terjadi berbagai macam penyakit. Secara umum faktor-faktor yang mempengaruhi kebutuhan nutrisi pada lansia terdiri dari: $2,8,9$

\section{a. Umur}

Metabolisme tubuh manusia mulai menurun setelah usia 50 tahun dan aktivitas fisik pun semakin berkurang. Setelah usia 50 tahun kebutuhan energi berkurang sebesar 5\% untuk setiap 10 tahunnya, sedangkan kebutuhan protein, vitamin, dan mineral akan tetap karena berfungsi sebagai regenerasi sel dan antioksidan untuk melindungi sel-sel dari radikal bebas yang dapat merusak sel-sel dalam tubuh.

b. Jenis kelamin

Pada pria memerlukan energi, protein, dan lemak yang lebih banyak dibandingkan pada wanita. Hal ini disebabkan karena postur tubuh, otot, dan luas permukaan pada pria lebih luas dari pada wanita, namun kebutuhan asupan makanan yang mengandung zat besi $(\mathrm{Fe})$ pada wanita cenderung lebih tinggi dari pada pria. Jika tidak cukup memperoleh zat besi, wanita yang masuk masa pre menopause akan mengalami menopause dini.

c. Aktivitas fisik

Pada lansia akan mengalami penurunan fisik yang berdampak pada berkurangnya aktivitas fisik sehingga kebutuhan energi juga berkurang. Lanjut usia dengan pekerjaan fisik yang berat memerlukan kebutuhan zat gizi yang banyak.

d. Kondisi kesehatan psikis dan mental Kondisi mental sangat berhubungan dengan asupan 
gizi pada lansia. Kondisi mental lansia yang tinggal di panti jompo dengan lansia yang menghabiskan masa tuanya dengan keluarganya memiliki perbedaan. Biasanya apabila lansia yang tinggal di panti jompo tersebut kurang bisa menyesuaikan diri dengan lingkungan akan terjadi stress sehingga berdampak dengan asupan gizi yang berimbas dengan penurunan berat badan.

\section{e. Pengobatan}

Meningkatnya usia menyebabkan seseorang menjadi rentan terhadap penyakit. Pada lansia terjadi turunnya daya tahan tubuh sehingga lansia harus mengkonsumsi obat-obatan dalam waktu yang cukup panjang, Pada dasarnya pengobatan tersebut dapat memperbaiki kondisi kesehatan dan meningkatnya kualitas hidup, tetapi efek samping dari obat-obatan tersebut dapat mempengaruhi proses penyerapan zat gizi pada lansia.

3. Jaringan lunak dan jaringan keras rongga mulut pada lansia

Jaringan lunak dan keras rongga mulut pada lansia akan mengalami perubahan. Pada jaringan lunak akan terjadi penipisan sel, penurunan proliferasi seluler, hilangnya lemak, dan elastisitas submukosa. Jaringan fibrotik akan meningkat disertai dengan perubahan degenerasi kolagen. Kondisi ini akan membuat jaringan lunak pada Lansia akan rentan terhadap trauma.

Pada jaringan keras rongga mulut lansia secara nyata akan terjadi perubahan pada email gigi. Email akan menjadi kurang permeabel dan menjadi tempat akumulasi stain. Dentin juga akan mudah rapuh Keadaan tersebut mengakibatkan mahkota gigi akan mudah retak. Gigi pada lansia akan mudah terjadi abrasi, erosi, dan atrisi. Erosi terjadi karena larutnya kalsium oleh asam. Abrasi merupakan terkikisnya lapisan email sehingga lapisan email akan berkurang atau hilang, hal ini disebabkan karena kebiasaan lansia sering mengunyah tembakau dan pemakaian protesa dengan menggunakan cengkram. Atrisi adalah hilangnya substansi gigi secara bertahap pada permukaan oklusal, insisal dan proksimal gigi karena proses pengunyahan. Hal ini terjadi karena pada lansia terbiasa dengan mengunyah sirih, kontak prematur, dan makanan yang bersifat abrasif. Perubahanperubahan yang terjadi pada jaringan lunak dan jaringan keras rongga mulut pada lansia dapat menyebabkan terjadinya perubahan fungsi pengunyahan sehingga mempengaruhi status gizi pada lansia. ${ }^{7,11,12,13,14,16}$

\section{PEMBAHASAN}

Gigi memiliki peranan yang sangat penting bagi kehidupan seseorang. Selain untuk estetik, gigi juga berperan dalam pemenuhan nutrisi dengan fungsi pengunyahan. Seiring dengan meningkatnya usia seseorang maka akan lebih rentan terhadap penyakit khususnya pada rongga mulut. Berikut adalah macammacam penyakit gigi dan mulut yang umum pada lansia, diantaranya: ${ }^{15}$

1. Karies gigi dan penyakit periodontal
Seseorang yang memasuki masa lansia sangat rentan berisiko penyakit kronis pada rongga mulut seperti karies dan penyakit jaringan periodontal. Hal tersebut karena adanya akumulasi plak. Apabila oral hygiene buruk maka akan timbul karies dan penyakit jaringan periodontal. Karies pada lansia biasanya sudah pada tahap mencapai pulpa hingga gigi sudah menjadi sisa akar sehingga diperlukan tindakan pencabutan, hal ini disebabkan mereka baru mau dirawat giginya apabila giginya belum terasa sakit.

Seiring dengan berjalannya usia, jaringan periodontal juga mengalami perubahan akibat proses penuaan. Penyakit jaringan periodontal yang sering dialami oleh lansia antara lain : resesi gingiva, gingivitis, periodontitis, kegoyangan gigi sehingga mengakibatkan kehilangan gigi, sehingga menyebabkan hilangnya fungsi pengunyahan yang pada akhirnya akan mempengaruhi status gizi pada lansia. $^{15}$

\section{Kehilangan gigi}

Kasus kehilangan gigi pada merupakan suatu hal umum yang sering ditemukan pada lansia. Kehilangan gigi akan mempengaruhi kurangnya asupan makanan yang disebabkan karena terganggunya fungsi pengunyahan sehingga menyebabkan terjadinya penyakit lainnya. Akibat dari kurangnya asupan makanan akan mengakibatkan turunnya berat badan pada lansia.

Menurut Parera (2012) kehilangan gigi merupakan masalah kesehatan mulut yang umum terjadi pada lansia. Hal tersebut terjadi karena fungsi pengunyahan terganggu secara bertahap sehingga terjadi perubahan diet dikarenakan lansia menghindari bahan makanan tertentu. Beberapa lansia memilih makanan yang sudah diolah daripada makanan segar yang harus dikunyah. Menurut Elham Elmani (2013) menyatakan bahwa lansia yang banyak mengalami kehilangan banyak gigi seringkali mengkomsumsi makanan yang kurang akan serat dan sering mengkonsumsi makanan yang mengandung lemak jenuh tinggi sehingga mempengaruhi kesehatan umum lansia. Oleh karena itu peran oral hygiene yang penting karena sangat berpengaruh terhadap status gizi lansia.

Penelitian yang dilakukan Hsiao (2015) kehilangan gigi dapat menyebabkan terjadinya penyakit kardiovaskular, stroke, dan dimensia. Penyakit gigi dan mulut ada kaitanya dengan proses infeksi. Jika proses infeksi ini terjadi terus menerus dalam waktu jangka panjang maka akan terjadi peningkatan protein C-reaktif yang akan mempengaruhi sistem saraf pusat pada manusia sehingga akan menyebabkan terjadinya dimensia dan stroke. $^{15}$

3. Xerostomia

Saliva didalam mulut memiliki banyak kegunaan diantaranya melindungi gigi dan mulut dan berfungsi pada sistem pencernaan. Saliva di produksi 
oleh kelenjar saliva dan fungsi dari kelenjar saliva digunakan untuk proses pencernaan yang diatur oleh sistem saraf sensorimotorik. Pada lansia akan terjadi atrofi kelenjar saliva yang disebabkan karena menurunnya proliferasi sel-sel yang terdapat pada kelenjar saliva mayor dan minor sehingga akan mempengaruhi kualitas dan kuantitas dari saliva, maka akan terjadi suatu gejala yang disebut dengan mulut kering atau dry mouth syndrome dan sering disebut juga dengan xerostomia. Efek dari xerostomia dapat menyebabkan terjadinya karies, penyakit jaringan periodontal, candidiasis dan bau mulut.

Faktor etiologi lainnya antara lain riwayat konsumsi obat-obatan (antihipertensi, antidepresan, dan antipsikotik), proses menua, dan oral hygiene yang buruk. Efek dari xerostomia ini adalah dapat mempengaruhi proses penelanan dan penurunan oral hygiene. Hal tersebut dapat mempengaruhi status gizi lansia. Terdapat banyak penelitian mengenai dampak dari xerostomia tetapi tindakan untuk kasus tersebut masih cukup rendah. Terapi yang sering dilakukan adalah pemberian artificial saliva dan obat untuk menstimuli saliva (pilocarpine).

Terapi paliatif lainnya yang disarankan adalah dengan menghindari konsumsi makanan yang panas, makanan yang kering, merokok dan alkohol, selain itu untuk meningkatkan kelembapan pada daerah mulut dianjurkan dengan penggunaan lip balm atau minyak zaitun. ${ }^{15,18,19}$

\section{Candidiasis}

Lansia sering mengalami candidiasis atau jamur pada mulut sehingga mulut terasa sakit dan nafsu makan menjadi berkurang, ini disebabkan karena secara histologis jaringan lunak pada Lansia akan terjadi penipisan epitel karena penurunan proliferasi sel-sel sehingga mudah sekali terjadi infeksi.

Efek dari xerostomia dapat mempengaruhi pertahanan mulut terhadap kuman sehingga timbul efek samping salah satunya yaitu candidiasis. Selain itu efek karena diabetes mellitus, penurunan sistem imun, defisiensi nutrisi dan pemakaian obat-obatan yang sering banyak dialami oleh lansia dapat juga menyebabkan terjadinya candidiasis.

Penelitian yang dilakukana oleg Gita (2009) Kasus terjadinya chronic atrophic candidiasis disebabkan karena para lansia tidak menjaga oral hygiene dan gigi tiruan yang selalu terpasang sepanjang malam. Hal ini akan menciptakan lingkungan yang kondusif bagi pertumbuhan candida $s p$ karena oksigen dan $\mathrm{pH}$ yang rendah akhirnya terjadi peningkatan perlekatan candida $s p$ pada akrilik. Kebersihan gigi tiruan juga harus disarankan oleh para lansia dengan selalu rajin membersihkannya setiap malam hari sebelum tidur. ${ }^{11,20}$

\section{RINGKASAN}

Lansia adalah manusia berusia diatas 60 tahun. Pada usia ini terjadi penurunan kemampuan fisik dan fungsi organ. Masalah yang sering dihadapi oleh lansia salah satunya adalah oral hygiene. Oral hygiene lansia yang buruk adalah salah satu faktor risiko terjadinya malnutrisi. Kondisi ini akan mengakibatkan penurunan kondisi umum dan kualitas hidup lansia.

Pada keadaan fisiologis, kondisi mulut manusia akan berubah seiring dengan bertambahnya usia. Jaringan lunak akan mengalami penipisan jaringan karena penurunan proliferasi sel sehingga mudah terjadi trauma. Pada jaringan keras seperti email dan dentin akan mudah rapuh. Usia lansia juga rentan terhadap penyakit mulut lainnya.

Secara umum penyakit gigi dan mulut yang sering terjadi pada lansia adalah karies, penyakit jaringan periodontal, kehilangan gigi, xerostomia, dan candidiasis. Keadaan tersebut akan menyebabkan terganggunya fungsi pengunyahan sehingga mempengaruhi status gizi lansia. Lansia lebih memilih makanan olahan daripada makanan yang segar dan lansia lebih sering mengkonsumsi makanan mengandung lemak jenuh yang tinggi. Pengaruh lainnya yang menyebabkan buruknya oral hygiene adalah diabetes mellitus, penurunan sistem imun, defisiensi nutrisi dan pemakaian obat-obatan.

Saran dalam kajian pustaka ini adalah perlu dilakukan penelitian pendahuluan dan lanjutan, karena dibutuhkan data-data terbaru di lapangan sehingga bisa menjadi solusi bagi kesehatan lansia di Indonesia khususnya masalah malnutrisi oleh karena pengaruh oral hygiene yang buruk pada lansia.

\section{REFERENSI}

1. Nidyawati. Soewantoro, Gambaran tingkat pengetahuan dam kebersihan mulut pada masyarakat lanjut usia di kelurahan Rurukan kecamatan Tomohon Timur. Jurnal Biomedik. 2015: 5 (1) : 169-174

2. Ibrahim. Hubungan faktor-faktor yang mempengaruhi kebutuhan gizi dengan status gizi lanjut usia di UPTD rumohseujahtera geunaseh banda aceh. Idea Nursing Journal. 2012: 3(2): 51-62

3. Razak, Ricard, Thankachan, Hafiz. Geriatric Oral Health: A Review Article. Journal of International Oral Health. 2014: 6(6): 110-116

4. Gambaran kesehatan lanjut usia di Indonesia. Buletin jendela data dan informasi kesehatan. Kementerian Kesehatan RI. 2013

5. Wijayanti. Hubungan kondisi fisik RTT lansia terhadap kondisi sosial di RW 1 RT05 kelurahan tegalsari kecamatan candisari.2008.Vol 7:1.38-49

6. Slamet, Suci, Aniq. Tingkat kemandirian lansia dalam activities daily living di panti sosial tresna werdha senja rawi. Jurnal Pendidikan Keperawatan Indonesia.2013. Vol2 : 1.16-21

7. Hsio, Ya ling, Shu y. Association between tooth loss, body mass index, and all cause mortality among elderly patients in Taiwan. Medicine Journal. 2015.Vol 94:39.1-8

8. Ziobolz, Werner. Oral health and nutritional status ain nursing home residents-result of an explorative cross sectional pilot study. BMC Geriatri. 2017. 17(39): 1-8

9. Muthmainah, Sofya, Rahmawati. Perbedaan status gizi lansia ditinjau dari penggunaan gigi tiruan dengan menggunakan metode mini nutrional assessment. Jurnal 
Caninus Dentistry. 2017:2(1): 40-47

10. Emami, Kawabat. The impact of eduntlism on oral and general health. Int J Dent. 2013:1-7

11. Kusuma, Nurviyandari. Status nutrisi lanjut usia di panti sosial dipengaruhi oleh status oral health. FIK UI.2014. $1-10$

12. Wijaya, Pramantara, Pangastuti. Status kesehatan oral dan asupan zat gizi berhubungan dengan status gizi lansia. Jurnal Gizi Klinik Indonesia. 2012: 8(3): 151-157

13. Pedoman Pelayanan Gizi Lanjut Usia. Jakarta: Kementerian Kesehatan Republik Indonesia 2012: 1-70

14. Nyakanen, Lonroos. Nutrional Screening in a populationbased cohort of community-dwelling older people. European Journal of Public Health. Vol 23:4. 405-409

15. Schimmel, Katsoulis. Masticatory function and Nutrition in old age. Swiss Dental Journal SSO.2015. Vol 125:4.449453

16. .Cousson, Bessadet. Nutritional status, dietary, intake and oral quality of life in elderly complete denture wearers. Gerondontology.2012;29.685-692

17. Montoya, Ferreira. Oral health in the elderly patient and it's impact on general well-being: a nonsystematic review. Clinical Intervention in Aging

18. Razak, Ricard. Geriatric Oral Health: A review article. Groatric Oral Health. 2014;6(6):110-116

19. Mesood, Newton. The Relationship between in oral health related quality of life among Elderly People in United Kingdom. Journal Dentistry.2017.78-83

20. Yao, Michael. Inequity in oral health care for elderly Canadians: Part 1. Oral Health Status, J Can Dent Assoc.2013;79:1-11 